\title{
Who Wrote Dido, Queen of Carthage?
}

\author{
RUTH LUNNEY AND HUGH CRAIG
}

UNIVERSITY OF NEWCASTLE, AUSTRALIA

The title page of the 1594 Dido, Queen of Carthage has the statement: "Written by Christopher Marlowe, and Thomas Nash. Gent." But who actually wrote the play?

This is an essay about evidence. In 2008 Martin Wiggins proclaimed the joint authorship of Dido, Queen of Carthage to be beyond doubt: "it is clear that, on the available evidence, the question editors should now be posing is not ... whether, but what, Nashe contributed to Dido." ${ }^{1}$ That assertion is reinforced in the second volume of British Drama (Wiggins \& Richardson), where the authors of Dido are recorded as Marlowe and Nashe. ${ }^{2}$

We will argue that the matter of Dido's authorship is not settled, that the question of "what"-Nashe's contribution to the play —needs to be looked at afresh on the basis of both "available" evidence and new evidence. This is a joint essay, an experiment in utilising both traditional and computational approaches, with their differing terminologies and expectations. One approach will evaluate the evidence already advanced for Nashe's presence in the play, with a particular focus on Wiggins's “available evidence.” A second, complementary approach, also addressing the authorship issue, reviews the evidence from computational stylistics and offers two new tests. Both approaches confirm Dido as Marlowe's.

We conclude with a reappraisal of Nashe's relationship with Dido.

This essay is dedicated to the memory of John Burrows (1928-2019).

An earlier version of the essay was "Commended" in the competition for the 2019 Calvin and Rose G Hoffman Prize for a Distinguished Publication on Christopher Marlowe. We had previously presented the arguments in two papers at the Eighth International Conference of the Marlowe Society of America in Wittenberg, Germany, in July 2018.

\footnotetext{
${ }^{1}$ Martin Wiggins, "When Did Marlowe Write Dido, Queen of Carthage?," Review of English Studies 59, no. 241 (2008): 526. Wiggins contends that Dido was written in the late 1580s, when Nashe was more likely to be co-author, but his assumptions are flawed. He argues that the play would not have been written for performance in 1580s Cambridge, but this does not preclude the play being written in the hope of performance at court, as Lyly's recently published plays had been; undergraduates may have been kept busy for eighteen hours a day, but Marlowe graduated BA in 1594 and was often absent from Cambridge thereafter, including from July to December 1584 (See Constance Brown Kuriyama, Christopher Marlowe: A Renaissance Life (Ithaca, NY: Cornell University Press, 2002), xiv-xv, 53-4); the lack of children's court performances from 1584 could not have been anticipated (Lyly's Gallatea was written by April 1585 but not performed till January 1588). Wiggins also suggests Dido must be a response to Tamburlaine because it is like The Wars of Cyrus in length, number of parts, and staging requirements (and both plays end with suicides); but these parallels are of dubious relevance.

${ }^{2}$ Martin Wiggins and Catherine Richardson, British Drama, 1533-1642: A Catalogue (Oxford: Oxford University Press, 2012-2018), 2: 444.
} 


\section{Searching for Nashe in Dido}

Where is Nashe in Dido? The "available evidence" that Wiggins relies upon, and which confirms for him the title page statement, is a particular set of editorial suggestions found in the 1968 Revels Plays edition of Dido: "the vocabulary and spelling evidence gathered by H. J. Oliver, who found Nasheisms scattered through the play, most prominently in the opening scene." ${ }^{3}$ Yet such verbal evidence needs to be treated with caution. In the New Oxford Shakespeare Authorship Companion, Gary Taylor and Rory Loughnane comment that "verbal parallels" in particular "have been used, misused, and abused more than any other species of internal evidence"; they urge that studies of vocabulary should focus upon "the overall structure and distribution of vocabulary, rather than individual words," recommending "relentless comprehensiveness" and/or the use of digital databases; indeed, "truly comprehensive tests of verbal parallels are only possible with digital databases." ${ }^{\prime 4}$ The first approach here attempts the "relentless." Despite the significant contributions of the digital (represented in this essay by our second approach), there is still a place for considering words in context, in the widest of senses, as embedded in patterns of expression, but also in patterns of thought, emotion, and imagination, as reflecting preoccupations, as sharing and modifying experience, of the author and reader and spectator. ${ }^{5}$

\section{Approach 1: the Available Evidence}

The search for Nashe has had a long, but largely unproductive history: a trail littered with labels, impressions, and verbal parallels. Brian Vickers cites the title page statement as definitive proof of collaboration, "publicly acknowledged," yet few writers have accepted it as sufficient. ${ }^{6}$ One early instance of following the title page is Edward Phillips in 1675, who simply recorded Marlowe's “tragedy of Dido, in which he was joined with Nash"; a few later commentators, George Hunter included, adopt "Marlowe and Nashe" without comment.

\footnotetext{
${ }^{3}$ Wiggins, "When," 526. Wiggins also cites here the authorship study of Thomas Merriam, "Marlowe and Nashe in Dido Queen of Carthage," Notes \& Queries 245 (December 2000): 425-8 (see our detailed discussion below in Approach 2), although he does comment that Merriam's findings "do not mesh together neatly" with Oliver's.

${ }^{4}$ Gary Taylor and Rory Loughnane, "The Canon and Chronology of Shakespeare's Works," in The New Oxford Shakespeare Authorship Companion, ed. Gary Taylor and Gabriel Egan (Oxford: Oxford University Press, 2017), 437, 435, 437. A similar point is made by Brian Vickers: "For many years writers on authorship issues have warned against the dangers of relying on verbal parallels, while continuing to use them" (Shakespeare CoAuthor: A Historical Study of Five Collaborative Plays (Oxford: Oxford University Press, 2002), 60).

${ }^{5}$ Vickers cites Muriel St Clare Byrne on the criteria for accepting verbal parallels as evidence, including "quality," in which both words and thought are parallel" (Shakespeare Co-Author, 58-9).

${ }^{6}$ Vickers, 11-12.

${ }^{7}$ Phillips, Theatrum Poetarum Anglicanorum (1675), cited in Millar Maclure, Marlowe: The Critical Heritage 1588-1896 (London: Routledge \& Kegan Paul, 1979), 52; G. K. Hunter, English Drama 1586-1642 (Oxford:
} 
More often, writers have played with labels, "improving" on the title page by proposing specific roles for Marlowe and Nashe. ${ }^{8}$ The pattern was set in the eighteenth century by Bishop Thomas Tanner: Nashe "perfecit et edidit," i.e., "completed or perfected" and "published" the play. ${ }^{9}$ Although Tanner may have had access to a copy of Dido (he cites the publication details and quotes the first line), he may not have had any special knowledge (he recycles the standard misinformation that Marlowe was an actor). His remarks, nevertheless, echo down the years, as in: "completed and published" (Thomas Warton 1781); completed for the 1590s stage (Alexander Dyce 1876); possibly prepared for the printer, making a few superficial changes (C. F. Tucker Brooke 1910); "literary executor" and possible transcriber (Roma Gill 1987). ${ }^{10}$

Much of the internal "evidence" cited for authorship has originated in impressions of Dido's dating and/or style. Was it written early or late? Was it revised? Was it "prentice work" or prompted by Tamburlaine's success? Does it deal with the French marriage or English imperialism? ${ }^{11}$ Notably, though, a good half of the critical essays on the play simply assume Marlowe was the author, with the issue relegated (if mentioned at all) to a note that redirects the reader to discussions elsewhere.

In impressionistic readings it is usually Marlowe who fares better. Nashe tends to be held responsible for the play's perceived failings, such as unevenness or immaturity or flawed construction. Hence Nashe writes "inferior passages," his efforts being "more monotonous in versification and less poetical." 12 A few nineteenth-century editors attribute the play largely

Clarendon Press, 1997), 345; others explicitly noting dual authorship include Deanne Williams: "written by Christopher Marlowe in collaboration with Thomas Nashe" ("Dido, Queen of England," English Literary History 73, no. 1 (2006): 31).

${ }^{8}$ Cf. Wiggins, "When," 522: "Much scholarly ingenuity has been devoted to finding a way not to have to take the evidence of the title page at face value."

${ }^{9}$ Cited in Ronald B. McKerrow, ed. The Works of Thomas Nashe, 5 vols, 1904-10, rev. ed. F. P. Wilson (Oxford: Basil Blackwell, 1966), 2: 336; a copy of Malone's letter with this information is attached to the Bodleian copy of Dido.

${ }^{10}$ Warton, History of English Poetry, 1774-81 (comment recorded by Malone), cited in Maclure, Marlowe: The Critical Heritage, 58; Alexander Dyce, ed., The Works of Christopher Marlowe: With Some Account of the Author, and Notes: A New Edition, Revised and Corrected (London: Routledge, 1876), xxxvi (Dyce cites the remarks of Tanner and Warton as his "evidence"); C. F. Tucker Brooke, The Works of Christopher Marlowe (Oxford: Clarendon Press, 1910), 389; Roma Gill, ed., The Complete Works of Christopher Marlowe, vol. 1, Translations (Oxford: Clarendon Press, 1987), 122. Gill's "literary executor" probably derives from Brooke, "The Marlowe Canon," PMLA 37, no. 3 (September 1922): 368.

${ }^{11}$ In order: "prentice work": John Bakeless, The Tragicall History of Christopher Marlowe (Westport, CT: Greenwood Press, 1942), 2:41; after Tamburlaine: Wiggins, "When”; French marriage: Donald Stump, "Marlowe's Travesty of Virgil," Comparative Drama 34, no. 1 (Spring 2000): 79-107; imperialism: Margo Hendricks, "Managing the Barbarian: The Tragedy of Dido, Queen of Carthage," Renaissance Drama 23 (1992): 165-88.

${ }^{12}$ See Bakeless, Tragicall History, 2:41-2, and J. P. Collier, History of English Dramatic Poetry (1831), 3:225 (cited in Dyce, Works, xxxvi). Collier maintained the shares were easily distinguishable, with (for example) Nashe responsible for the tale of Troy in act 2. 
to Nashe on the grounds of quality. The "Hurst" edition of 1825 opts for Nashe as main author, despite his lack of "dramatic talent," claiming that the play itself "is little more than the narrative taken from Virgil, constructed according to the form of a drama, but containing little of the essence of that species of composition." ${ }^{13}$ Perhaps Nashe's only real defender is Alexander Grosart, who admires his "vigour" and manliness. Grosart bases his impressions on "vocabulary and phrasing"; he writes of Marlowe: "his 'mighty line' is scarcely once found; nor even his choice epithets except in a very few cases, and even these few so mixed up with Nashe's self-evidencing bits as to be doubtful."14 At the same time, Grosart did not "dare ... attempt to separate between the Marlowe and Nashe portions." ${ }^{15}$ Indeed the two quantitative attempts to do so have produced unconvincing results: F.G. Fleay (1891) employs tables of versification to assign authorship of particular scenes, and Thomas Merriam (2000) uses a limited "logometric analysis" (five common words only) to divide the play into two halves, assigning Act 1 and 2 to Marlowe (parallel with Tamburlaine) and Acts 3-5 to Nashe (parallel with Summer's Last Will and Testament). ${ }^{16}$ The recent study of Darren Freebury-Jones and Marcus Dahl uses the online database EEBO-TCP to explore rhyme in Dido, finding that "there is compelling evidence for Marlowe's rhyming habits throughout the text," in contrast to earlier views such as Bullen's that rhyming suggests the presence of Nashe. ${ }^{17}$ The article is discussed in more detail below, in Approach 2.

Beyond impressions and general comments on style and preoccupations, most of the "available evidence" has consisted of verbal parallels, almost all of them "proving" Marlowe's authorship. ${ }^{18}$ Brooke and Bakeless have pages of parallels between Dido and other Marlowe texts. ${ }^{19}$ Despite his commitment to Nashe's "self-evidencing bits," Grosart

\footnotetext{
${ }^{13}$ Hurst, ed., Dido, Queen of Carthage: A Tragedy, by Christopher Marlowe and Thomas Nash (London: Hurst, Robinson \& Co., 1825), xii. Similar comments are found in the Oxberry edition: the play was chiefly written by Nashe, being "little more than a series of translations of passages from the 2d, 3d, and 4th books of the Aeneid": W. Oxberry, ed., Dido, Queen of Carthage: A Tragedy, by Christopher Marlowe (London, 1818-1820 or 1827), i-ii.

${ }^{14}$ Alexander Grosart, ed. The Complete Works of T. Nashe (The Huth Library, 1885), 6:xxii. Italics in original.

${ }^{15}$ Grosart, 6:xxi-xxii.

${ }^{16}$ See F. G. Fleay, Biographical Chronicle of the English Drama, 1559-1642, 3 Vols (1891), 2:147, cited in McKerrow, ed., Works, 4:294-5, and Merriam, "Marlowe and Nashe in Dido." Fleay assigns the following to Nashe: 1.1.122-end; 3.1, 2, 4; 4.1, 2, 5 (the gods and courtship feature in both shares). Merriam's study is discussed in more detail below.

${ }^{17}$ Darren Freebury-Jones and Marcus Dahl, "Searching for Thomas Nashe in Dido, Queen of Carthage," Digital Scholarship in the Humanities 35, no. 2 (2020): 304; A. H. Bullen, ed., The Works of Christopher Marlowe (London: Nimmo, 1885), 2:306.

${ }^{18}$ Some older studies analyse metre and versification, but essentially in terms of Marlowe's "development" rather than as related to authorship; see, e.g., Brooke, "Marlowe's Versification and Style," Studies in Philology 19, no. 2 (April 1922). For the more recent quantitative studies of Oras and Tarlinskaya, see Approach 2.

${ }^{19}$ See Brooke, "Canon," 372-4 and Bakeless, Tragicall History, 2:47-64. Brooke comments that the parallels do not "prove anything definitely in regard to the date of Dido" (374). Bakeless notes that some instances
} 
provides only minimal evidence: he selects the single word "attract" (1.1.136) as "certain" and representative proof of Nashe's "bits," and directs the reader to his "Glossarial Index"-where he cites two parallels and is sidetracked into etymology. ${ }^{20}$ Occasionally, writers have noted parallels with Nashe, citing individual words or allusions, but have then eventually downplayed them: before Oliver, Boas listed seven instances (two allusions and five words) but maintained that the play has "the stamp of Marlowe." And although McKerrow includes Dido in his five-volume edition of Nashe's works, he concludes: "Dido seems to throw no light whatever on the rest of Nashe's writings or to be in any way connected with them" $(4.295) .^{21}$

\section{Oliver's List}

After this history of labels, impressions, and verbal parallels, Oliver's 1968 edition offered the prospect of fresh "available evidence." His introduction provides a list of sixteen items: particular spellings, words "found elsewhere in Nashe but not in Marlowe," and classical allusions he regards as more closely paralleled in Nashe. ${ }^{22}$ Many of these "Nasheisms" (in Wiggins's handy term) are inherited from the considered or casual remarks of McKerrow, Wilson (McKerrow's reviser), Brooke, Boas, and the nineteenth-century editors; others derive from Oliver's own observations. ${ }^{23}$ At last, it seemed, there was substantial evidence for Nashe's presence in Dido.

\footnotetext{
"sound like first drafts for later and better work in other plays" (47); he also includes parallels with Nashe, Kyd, and Shakespeare (65-8). Parallels with Kyd are listed by T. M. Pearce in arguing that Dido was written, or at least prepared for the stage, in 1591 when Marlowe and Kyd were sharing a chamber. See "Evidence for Dating Marlowe's Tragedy of Dido," in Studies in the English Renaissance Drama, ed. by Josephine W. Bennett, Oscar Cargill, and Vernon Hall, Jr. (New York: New York University Press, 1959), 240-46.

${ }^{20}$ Grosart: "one might have set down a passage in 'Dido' as most certainly Marlowe's, but in it occurs a so singularly used Nashe word as to certify it to be his. See Glossarial Index, under 'Attract.' And so throughout." [my italics]. Works of T. Nashe, 6:xxii. The Glossarial Index information (6:176) is limited to noting parallels with Nashe's Summer, the item reading: “Attract, vi.13, 124 ['Dido', line 139, 'Summer', line 938] = to draw to or on. Had it not thus occurred twice, and independently, we might have suspected error for 'attrect,' from 'attrecto,' I handle."

${ }^{21}$ Frederick S. Boas, Christopher Marlowe (Oxford: Clarendon Press, 1940), 50. McKerrow provides minimal annotation for Dido, commenting: "It seems clear from the general evidence of style that the greater part of the work is Marlowe's, but what share, if any, Nashe had in it is very difficult to decide" (4.294). Mary Elizabeth Smith, in the only monograph on the play, concludes that "from the standpoints of tone, image, and theme ... there is nothing in the play that Marlowe could not have written": "Love Kindling Fire": A Study of Christopher Marlowe's The Tragedy of Dido Queen of Carthage (Salzburg: Institut für Englische Sprache und Literatur, Universität Salzburg, 1977), 161.

${ }^{22}$ H. J. Oliver, ed., Dido, Queen of Carthage and The Massacre at Paris (Manchester: Manchester University Press, 1968), xxii-xxv.

${ }^{23}$ See McKerrow, Works of Thomas Nashe; Brooke, ed. The Life of Marlowe and the Tragedy of Dido (1930; repr. New York: Gordian, 1966).
} 
At the same time, Oliver speculates rather than insists. He comments that word "tests" are "somewhat old-fashioned, and dangerous," noting the "statistical probability that in any one work an author will use some words that he does not use elsewhere." ${ }^{24} \mathrm{He}$ sums up his "observations" as "at best, straws in the wind." 25 And, indeed, many of Oliver's inherited Nasheisms began life as illustrations, as cited parallels rather than evidence of authorship. Nevertheless, Oliver's influence can be seen in the attempts of subsequent editors to accommodate his suggestions. Gill finds the number of parallels suggested by Oliver in 1.1 "surprisingly high" but comments that "on each occasion the phrasing is undoubtedly Marlowe's"; she raises the possibility of Nashe as transcriber "introducing intermittently some of his own spelling peculiarities." 26 Similarly, the editors of the most recent Penguin edition (Romany and Lindsey) note that "Some traces of Nashe's vocabulary have been found in the play (though there are more of Marlowe's), but no one has succeeded in dividing the text between them." 27

Even so, and for fifty years, Oliver's suggestions have bolstered the case for Dido as a collaborative text. Along the way, however, his "straws" have turned into something more substantial. In Wiggins's 2008 essay, he comments that Oliver "found Nasheisms scattered through the play." 28 In British Drama (2012), the "Nasheisms" have become the proof of coauthorship: "Oliver detects vocabulary evidence for Nashe's presence in 1.1-2, 2.1, 3.1, 3.3, 4.3-4 (especially 1.1) and spelling evidence in 1.1, 4.4, 5.1." ${ }^{29}$ With one scene in both lists, that is nine scenes, out of thirteen in modern editions, or most of the play. The four scenes not listed are: 3.2 (goddesses), 3.4 (cave), 4.1 (exiting the cave), and 4.2 (Iarbas's sacrifice). The implication is that Nashe's contribution is not insubstantial.

Is the matter proven? For fifty years, Oliver's suggestions have been accepted or ignored, but never seriously challenged. To do so is one aim of this essay. Oliver implies, and Wiggins assumes, that the mere accumulation of instances is weighty enough to establish Nashe's presence in Dido - without evaluating the consistency of the selection criteria or the reliability of each item as evidence. The discussion which follows is based on an analysis of each item of Oliver's “available evidence," considering its use and meaning in context, in

\footnotetext{
${ }^{24}$ Oliver, xxiii.

${ }^{25}$ Oliver, xxv.

${ }^{26}$ Gill, Complete Works, 122.

${ }^{27}$ Frank Romany and Robert Lindsey, eds, Christopher Marlowe: The Complete Plays (London: Penguin, 2003), 564. The most recent Everyman edition does not mention the authorship issue: Mark Thornton Burnett, ed., Christopher Marlowe: The Complete Plays (London: Dent, 1999).

${ }^{28}$ Wiggins, "When," 526.

${ }^{29}$ Wiggins and Richardson, British Drama, 2:444.
} 
Dido and in the texts of both Nashe and Marlowe, and assessing its relevance for any wider patterns of thought, emotion, and imagination. ${ }^{30}$

Oliver's "Nasheisms," in order of discussion, are: bed-red (2.1.250), hoysing/hoysed (4.4.15; 4.4.153), ${ }^{31}$ eternish (1.1.108), famoused for (1.2.21; 5.1.275), man of men (3.3.26), Atlas ... underprops (1.1.98-9), shelves (1.1.147; 3.1.107; 4.4.58), ${ }^{32}$ Gaetulian (3.3.19), Dolon (1.1.70-2), [take] soil (3.3.61), ticing (2.1.145; 2.1.300; 4.3.31; 5.1.249; tice, 5.1.277), Vulcan dancing (1.1.32), exhaled (1.1.25), attract (1.1.136), Megaera's eyes (2.1.230), glassy fields (4.3.11). ${ }^{33}$ There are immediate problems with Oliver's list. It is inconsistent, with several items appearing in a form not found in Nashe, or where Marlowe texts have related forms. "Ticing," for example, is not found in either Nashe or Marlowe, although both use the form "tice." Nor could most of the items be justified by frequency. Twelve of the sixteen occur three times or fewer amongst the many thousands of words in Nashe's writings, eight of them only once. ${ }^{34}$ A few are Nashe favourites (“Atlas," "exhaled," "attract”), but these are by no means uncommon or rare at the time. Indeed, it is not difficult to find instances of Oliver's Nasheisms in other authors. ${ }^{35}$

\footnotetext{
${ }^{30}$ For more detailed analysis of each item, see 'Appendix 2: Authorship Glossary' in the new Revels Plays edition of Dido, edited by Ruth Lunney (forthcoming); additional information is available online: see "Who Wrote Dido, Queen of Carthage? An Authorship Glossary": http://hdl.handle.net/1959.13/1416114. In the discussion below, Marlowe texts are cited from the Revels editions, including the forthcoming edition of Dido, Queen of Carthage, edited by Ruth Lunney. References to Nashe texts are taken from McKerrow's edition; the form of references is "volume.page.line," except for Summer which is volume.page.TLN. Short titles used for Nashe texts are: Lenten (Nashes Lenten Stuff); Menaphon (Preface to Menaphon); Pierce (Pierce Penniless, His Supplication to the Devil); Saffron-Walden (Have with You to Saffron-Walden); Summer (Summer's Last Will and Testament); Tears (Christ's Tears over Jerusalem); Traveller (The Unfortunate Traveller).

${ }^{31}$ Oliver does not comment on the three instances of "hoyst" (3.3.47; 4.4.103; 5.1.227), modernising them as "hoist"; cf. his spellings "hoising" and "hoised."

${ }^{32}$ Shelves at 1.1.47 refers to submerged ledges of rocks, deriving from the narrative.

${ }^{33}$ Oliver's list had a varied ancestry, mostly as literary parallels suggested by earlier editors, usually without authorship implications: "Vulcan" (Hazlitt, Bullen), "attract" (Grosart), "Dolon" (McKerrow); "exhaled," "famoused (for)," "hoysing," "(take) soil," "Gaetulian," "shelves" (Brooke); Boas (50) lists seven of these (he omits "exhaled" and "[take] soil") as "some rare words, or with unusual meanings, found in Nashe and not elsewhere in Marlowe"; two items ("glassy fields" and "Megaera's eyes") derive from Charles Crawford's marginalia in a copy of McKerrow's Nashe.

${ }^{34}$ Only once in Nashe texts? Eternish, famoused for, man of men, Gaetulian, Dolon, Vulcan dancing, Megaera's eyes, glassy fields. Twice? [Take] soil. Three times? Shelves, bed-red, ticelticeth (not ticing). The "high" number of Nasheisms in the first 150 lines (labelled by Oliver as "curious," by Gill as "surprisingly high," and by Wiggins as occurring "most prominently") is less significant than it might appear: of the seven instances, two are commonplace classical allusions, one is a variant spelling, and one ("shelves") is appropriate to the narrative; the others ("Vulcan dancing," "exhaled," and "attract") are discussed in detail below. Frequencies for Nashe are based on Louis Ule, A Concordance to the Works of Thomas Nashe. 2 vols (Zurich: OlmsWeidemann, 1997), with additional reference to McKerrow, Works. Frequencies for Marlowe are based on Robert J. Fehrenbach, Lea Ann Boone and Mario A. Di Cesare, A Concordance to the Plays, Poems, and Translations of Christopher Marlowe (Ithaca, NY: Cornell University Press, 1982).

${ }^{35}$ A search of the glossary in Crystal and Crystal reveals at least ten of these items in Shakespeare texts, including an allusion to the Dolon story under "Rhesus." See David Crystal and Ben Crystal, Shakespeare's Words: A Glossary and Language Companion (London: Penguin, 2002).
} 
To briefly summarise the minor or less persuasive instances (nine of them). Those reliant on spelling are unconvincing, and not only because too much could intervene between manuscript and printed text. ${ }^{36}$ In any case, the "-red" spelling in "bed-red" is usual in the sixteenth century, with "bed-rid" more common from 1600. ${ }^{37}$ The "oy" in "hoysed" or "hoysing" (forms of the term occur five times in Dido) is a common variant along with "oi" and "y" (Nashe texts have both "oy" and "oi"). Indeed, Marlowe texts have forms of both terms ("bed-rid" and "hoist/ed"). Two briefly fashionable terms, "eternish" and "famoused for," are found in other authors: "eternish" in the 1580s (Lyly, Greene), "famoused for" mostly in the 1590 s with a few seventeenth-century instances (cf. Shakespeare, Son. 25: "The painful warrior famousèd for might"); they are relatively rare but could not on frequency be classified as Nashe markers. ${ }^{38}$ The phrase "man of men" is proverbial (OED cites instances 1470-1887), and the allusion to Atlas, while a Nashe favourite, is a commonplace. ${ }^{39}$ "Shelves" for sandbanks is not uncommon and is consistent with a narrative of seafaring. "Gaetulian" is a label in both Virgil and Ovid for Iarbas. The allusion to intercepting Dolon in Dido is closer to the source story in Homer than Nashe's vague recollection, probably of Ovid's Heroides. ${ }^{40}$

\footnotetext{
${ }^{36}$ Bowers comments in his "Textual Introduction" that: "the compositorial characteristics are in general so even as to conceal any evidence that might have been available in the printer's copy as to the assignment of authorship. The same relative uniformity prevents any guesses about the nature of the manuscript that underlies the print, whether holograph papers of one or of both authors, or else a transcript" (Fredson Bowers, ed. The Complete Works of Christopher Marlowe, Vol. 1 (Cambridge: Cambridge University Press, 1973), 4). Wiggins and Richardson suggest the printing was "probably from authorial copy," while Brooke and Melnikoff opt for a theatrical transcript. See, respectively, Wiggins and Richardson, British Drama, 2:444; Brooke, "Canon," 368 and Kirk Melnikoff, Elizabethan Publishing and the Makings of Literary Culture (Toronto: University of Toronto Press, 2018), 146. Oliver suggests only one compositor, though he also attempts to find traces of authorial spellings. He comments on certain spelling inconsistencies, which may be authorial but are quite likely attributable to transcribers or compositors; the passages he notes as affected are: 1.1.1-160 ("aire," "thine"); 4.4 ("hoysing," "the emperiall," "Punike," "in my steede"); 5.1, Hermes scene ("the Empire," "thine," Sergestus/Achates confusion). See Oliver, Dido, xxiv-xxv. Oliver's "my"/"mine," "thy"/"thine" discussion is misleading, as this is more a question of usage than authorship, with "my" or "thy" used for emphasis before a word beginning with a vowel; see E. A. Abbott, A Shakespearian Grammar, rev. ed. (New York: Haskell House, 1972), 237.

${ }^{37}$ See OED: the spelling is "bed-rid" in Marlowe, Lucan (1600) 1.502-3, and in Q1 Hamlet (1603) B2v.

${ }^{38}$ All references to works by Shakespeare are to Gary Taylor, John Jowett, Terri Bourus and Gabriel Egan, eds, The New Oxford Shakespeare: The Complete Works (Oxford: Oxford University Press, 2017).

${ }^{39}$ The "Atlas"-"underprop" combination is found once, in Pierce 1.184.14-15, plus "Atlas-like" and "prop" in Summer 3.245.372. Nashe uses "Atlas" and related forms ("Atlas-like," "Atlassed," "Atlassing") nine times, as against four times in Marlowe; "underprop" and forms occur seven times in Nashe, and once in Marlowe (Doctor Faustus, 3.1.34).

${ }^{40}$ The parallel is suggested by McKerrow (Works, 4:261), who comments that "the passages seem too much alike to be independent," with lines 70-81 representing "Nashe's addition to fill a gap." The relevant passage is Traveller (2.220.2-4): "Ulysses, Nestor, Diomedes, went as spies together in the night into the tents of Rhesus, and intercepted Dolon, the spy of the Trojans." Nashe labels them "Roman worthies," adds Nestor, and reverses the time sequence: in the Iliad, Dolon is intercepted and killed before Ulysses and Diomedes steal into the tents of Rhesus; in Ovid, Heroides, 1.39-40, the story is attributed to Nestor, and Rhesus's death is listed before Dolon's. The story is also referred to in 3H6 4.2.19-20.
} 


\section{"Where am I now? These should be Carthage walls." Or, Context Matters.}

Relative frequency of use is but one gauge: attending to context can be more telling, encompassing the verbal analysis of "the whole complex pattern of an author's vocabulary." ${ }^{41}$ In Nashe's works, the "Nasheisms" identified by Oliver occur in contexts very different from those in Dido, ones imprinted with his own characteristic patterns of thought, emotion, and imagination. Nashe is a provocative writer, forever seeking stories and sayings and images that can be wittily manipulated to make a point (or skewer an opponent). The Nasheism "soil" illustrates the process. In Dido's hunting scene (3.3), "soil” is a technical term referring to the water or swampy place where an animal seeks refuge. The supposed parallel in Nashe, in Christ's Tears over Jerusalem, serves as an anecdote with a moral message: take no pride in sin. Nashe exhorts London to be ashamed of her sinfulness - why, even the deer regrets sexual intercourse:

Doth the buck (having befilth himself with the female) lift up his horns and walk proudly to the lawns? O no, he so hateth himself (by reason of the stench of his commixture) that all drooping and languishing, into some solitary ditch he withdraws himself, and takes soil, and batheth till such time as there fall a great shower of rain, when being thoroughly washed and cleansed, he posteth back to his food.

A preoccupation with wrongdoing — in this case criminal activity — is also seen with the Nasheism "ticing" (or actually the forms "tice" and "ticeth," as "ticing" does not occur). In Tears, Nashe rails against brokers and usurers (the sixteenth-century equivalents of financial advisors and bankers): "If one tice a prentice to rob his master, it is felony by the law; nay, it is a great penalty, if he do but relieve him and encourage him, being fled from his master's obedience and service. And shall we have no law for him that ticeth a son to rob his father?" (2.97.16-20). Or, in Traveller, he produces a Jewish supervillain to out-Barabas Barabas: "I'll tice all the young children into my house that I can get, and cutting their throats barrel them up in powdering beef tubs, and so send them to victual the Pope's galleys" (2.311.7-10). Context matters. Dido's five instances of "ticing" or "tice," with their suggestions of mysterious powers or sexual allure - applied to speech as persuasive as "Hermes' pipe," to Helen, Dido, Aeneas's "relics," and the magic of music — are closer in sentiment to Marlowe's related uses elsewhere: Theridamas's response to Tamburlaine: “What strong

\footnotetext{
41 Taylor and Loughnane, "Canon and Chronology," 435.

${ }^{42}$ Nashe's only other use of "soil" in this sense also has a moral point, as a comment on a woman's desperate plea to avoid being raped: "Deer oppressed with dogs, when they cannot take soil, run to men for succour; to whom should women in their disconsolate and desperate estate run but to men (like the deer) for succour and sanctuary" (Traveller 2.290.6-10). The phrase "soiled by sin" occurs four times in Tears.
} 
enchantments tice my yielding soul? ... Won with thy words and conquered with thy looks" (1 Tamburlaine 1.2.223, 227), or to the warning in the Faustus Epilogue against "unlawful things, / Whose deepness doth entice such forward wits / To practise more than heavenly power permits" $(6-8) .{ }^{43}$

The most plausible parallel with Nashe is the reference to Vulcan dancing, an unusual notion when elsewhere in the period he is cited for lameness, blacksmithing, or netting Mars and Venus. ${ }^{44}$ In this case Nashe wittily exceeds the absurdity of Dido's passing reference ("Vulcan shall dance to make thee laughing sport," 1.1.32) to offer a lengthy compliment to Summer's audience (they are "gods") and an apology for his actors:

To make the gods merry, the celestial clown Vulcan tuned his polt foot to the measures of Apollo's lute, and danced a limping galliard in Jove's starry hall. To make you merry, that are the gods of art and guides unto heaven, a number of rude Vulcans, unwieldy speakers, hammer-headed clowns ... have set their deformities to view, as it were in a dance here before you. Bear with their wants, lull melancholy asleep with their absurdities, and expect hereafter better fruits of their industry.

$(3.294 .1930-40)$

\section{"Love kindling fire, to burn such towns as Troy" (Hero and Leander 1.153)}

It could be objected that in such instances, the terms still mean the same, that any apparent differences simply result from genre and intention, that parody and satire and invective are expected to operate within a restricted emotional range. Other proposed Nasheisms, however, like "ticing" [Nashe: "tice"], have pointed to the very different patterns of thought and imagination that are intrinsic to Dido, and characteristic of Marlowe. This is so, even of the two potentially most plausible Nasheisms, "exhaled" and "attract." These are relatively common words, not peculiar to Nashe, but which occur multiple times in Nashe and-in these specific forms - not elsewhere in Marlowe.

And yet, both terms are embedded in Dido within a distinctive Marlovian pattern —of eyes and fire and immense natural forces - that expresses the experience of love. Lovers have

\footnotetext{
${ }^{43}$ The original spelling in both A- and B-texts is "intice."

${ }^{44}$ The source of this allusion is obscure. Bullen cites Hazlitt, Dodsley's Old Plays 8.91, as noting the parallel, but suggests the Iliad 1.595-600, where the lame Vulcan caused the gods to laugh as he bustled about, serving wine (2:304). McKerrow (Works, 3.296) suggests a possible source in Erasmus, Praise of Folly (1509), 85, alluding to the same incident; a misreading is possible, as the Vulcan mention is followed by reference to three different figures or groups dancing to entertain the gods. Another possible source is Rabelais, in the "Author's Prologue" to the Fourth Book of Pantagruel (1552), where, following the story of the woodcutter's axe, Vulcan celebrates his love: "Vulcan, avec sa jambe torte, en feist pour l'amour de s'amie, trois ou quatre beaulx petitz saux en plate forme"; there was no sixteenth-century English translation, with later translations of "saux" being "hops" or "jumps" rather than "dancing." See Rabelais, Le quart livre des faits et dits heroïques du bon Pantagruel (1552; Egham, Surrey: Runnymede Books, 1990), 42.
} 
always burnt for love, but in Marlowe the beloved's eyes send out the fire to keep that fire burning. The image may be conventional, but the special emphasis is Marlowe's. A small but telling instance is the change Marlowe makes when he translates 3.11 in Ovid's Amores. Ovid's mistress has eyes that capture the poet's; the Loeb translation is "And by your eyes, that have taken captive mine" ("perque tuos oculos, qui rapuere meos," Amores, 3.11.48). Marlowe's mistress has eyes of fire: "And by thine eyes whose radiance burns out mine" (AOE, 3.10.48). Those fiery eyes feature in Tamburlaine. Zenocrate's eyes "shot fire from their ivory bowers" (2 Tamburlaine 2.4.9), inspiring love, fostering vitality, and lighting up the moon, planets, and meteors (1 Tamburlaine 5.1.147-50). Tamburlaine's are part of his charisma ("His looks do menace heaven and dare the gods; / His fiery eyes are fixed upon the earth," 1 Tamburlaine 1.2.156-7); his true heir must be capable of sending "lightning from his eyes" (2 Tamburlaine 1.3.76), the weapon of Jupiter.

As for Jupiter himself, in Dido, he defines his exchange of glances with Ganymede in terms of fire: "Whose face reflects such pleasure to mine eyes / As I, exhaled with thy firedarting beams, / Have oft driven back the horses of the night" (1.1.24-5). The fire sent by Ganymede's eyes is drawn up, intensified, and re-transmitted, perhaps as meteors or lightning, to turn back time (1.1.24-5). Jupiter's "exhaled," as often in sixteenth-century texts, has the sense of "drawn up"; Marlowe texts may not use the exact word, but the related term "exhalations" does occur four times, used to refer to substances or qualities (as moisture or heat) that were drawn up by the sun to become "meteors," then a general term for meteorological phenomena (wind, rain, even lightning). ${ }^{45}$

The second of these multiple-use Nasheisms, "attract," in the obsolete sense of to "take in" or "absorb," also connects to the pattern of eyes and love. When Venus sights Aeneas, she remarks that she is now "content / The while thine eyes attract their sought-for joys" (1.1.135-6). In Dido, eyes are active, not just shooting out fire but constantly seeking out the objects of perception, transmitting as well as receiving emotion. Aeneas needs rescuing from the "gross eye-beams" of the common people (3.1.72-3); Iarbas flees Anna's “alluring eyes"; and Dido's eyes are cast "like anchors out / To stay my fleet from loosing forth the bay" (4.3.25-6).

\footnotetext{
${ }^{45}$ On "exhalations," see Heninger, A Handbook of Renaissance Meteorology: With Particular Reference to Elizabethan and Jacobean Literature (Durham, NC.: Duke University Press, 1960), 37-46; 72-134. Marlowe instances include "fiery exhalation" (1 Tamburlaine 4.2.43); "windy exhalations" (1.2.50); and the related "heaps of ... fiery meteors" (2 Tamburlaine 3.2.3).
} 
Marlowe does not elsewhere use "attract" but Tamburlaine has "attractive" in a sense close to the powerful eyes of Dido: for Theridamas, "Such power attractive shines in princes' eyes," which are not merely admirable but have the active power to gain possessions ("to ask, and have"), compel obedience ("command, and be obeyed"), and even by their "looks" to "breed love" (1 Tamburlaine 2.5.62-4). Something of the same quality may be suggested in Helena's envious description of Hermia's "blessed and attractive eyes" (MND 2.2.97). And what of Nashe? Except in parody, Nashe constructs no comparable pattern to express the experience of love. He too has learnt his lessons from Ovid, but his response is quite different. Of women and love Nashe writes wittily, and often misogynistically. Helen is never glamorous or even "ticing" but merely a whore. ${ }^{46}$ In Traveller - apart from the Earl's elevated nonsense about Geraldine ("Perch thou, my spirit, on her silver breasts," 2.254.20) — the most favourable portrait of a woman is Jack Wilton's beloved, Diamante, a bird-like figure:

A pretty round-faced wench was it, with black eyebrows, a high forehead, a little mouth, and a sharp nose, as fat and plump every part of her as a plover, a skin as silky and soft as the back of a swan .... Like a bird she tripped on the ground, and bore out her belly as majestical as an ostrich. With a lickerous [wanton] rolling eye fixed piercing on the earth, and sometimes scornfully darted to the one side, she figured forth a high discontented disdain. (2.261.4-13)

Diamante's eyes "pierce" in the conventional manner; indeed, for the besotted Earl, love is the king of piercing eyes (2.243.11-15). With one exception (of which, more later), the closest he gets to Marlowe's fiery love is a piece of Petrarchan sentimentality: "Her high exalted sunbeams have set the Phoenix nest of my breast on fire" (2.243.12-13). ${ }^{47}$ The patterns of thought and emotion Nashe associates with "exhaled" and "attract" are far removed from Dido's images of fire and eyes and immensity. Most instances of "exhaled" in Nashe texts refer to harmful things being drawn up either by the sun or by some spiritual or political power. ${ }^{48}$ Thus, Summer claims that Autumn stinks from "exhaling" the vilest dunghills (Summer 3.248.481-2); preachers “exhale” foolish superstitions from people's

\footnotetext{
${ }^{46}$ Nashe on Helen: one of the "unclean sisters" to be "speedily" carried to hell (Pierce 1.217.3); "The poets were trivial, that set up Helen's face for such a top-gallant summer may-pole for men to gaze at .... Wise men in Greece ... to swagger so about a whore" (Lenten, 3.184.27-34); and, more reminiscent of Marlowe, "the attractive melting eye of that strumpet" (Lenten, 3.185.4). Helen is, of course, sometimes a "strumpet" in Marlowe: cf. "Greekish strumpet" (Edward 2.5.15).

${ }^{47}$ Nashe's target here is most likely The Phoenix Nest, a poetic miscellany published in 1593.

48 "Exhale" and related forms occur sixteen times in Nashe texts ("exhaled," "exhaling," "exhalations"). The other "exhaled" in Dido (5.1.14) refers to "rich odours ... exhaled" by the sun, a physical process similar to Nashe's "The sea, exhaled by drops, will in continuance be dry," before he continues "and Seneca, let blood line by line and page by page, at length must needs die to our stage" (Menaphon 3.316-17).
} 
minds (Lenten 3.197.28); and if the authorities cannot "exhale" the "excrements" of society, i.e., unemployed soldiers, they will need "some light toys to busy their heads withal," plays, for instance, "which may keep them from having leisure to intermeddle with higher matters" (Pierce 1.211.28-33). "Exhale" in this sense is not uncommon: McKerrow notes related uses in Greene; $O E D$ adds Chapman; and Crystal and Crystal cite instances from Shakespeare, including Lady Anne's accusation $(R 3,1.2 .58)$ that Richard's mere presence "exhales" the blood from Henry VI's corpse. ${ }^{49}$

In Nashe, "attract" usually relates to mental processes - to understanding or imagining ideas and information — rather than, as in Dido, to power and physical perception. ${ }^{50}$ Pierce Penniless asks: "Or canst thou not attract the true image of hypocrisy, under the description of the Fox and the Chameleon?" (1.226.31-3). Tears evokes the torments of hell as "A hundred thousand thousand times more than thought can attract, or supposition apprehend" (2.168.26). Even when Nashe mentions perception, the point of the comment is a mental process: "I must give credit unto what I hear; / For other than I hear, attract I ought" (Summer, 3.260.866-7).

\section{"Megaera's eyes"}

The two remaining Nasheisms, "Megaera's eyes" and "glassy fields," are found in Lenten, in mock-heroic descriptions of the fishing industry. This, Nashe's final work, was published in 1599, five years after Dido, and these Dido parallels join other Marlovian echoes (Hero and Leander end up as fish), as well as expressions such as "the topless tottering hills" of the sea (3.203.13), in affectionate parody. "Megaera's eyes" belong not to Dido's bloodthirsty Pyrrhus "threatening a thousand deaths at every glance" (2.1.231) but to an upper-class fish defending her "buskie grove" from a nasty-looking herring (Lenten 3.217.6-9). And the "glassy fields of Thetis" (in Dido they are Neptune's) become the fishing grounds of the herring fleet (3.183.12-13).

As these final items of Wiggins's "available evidence" suggest, the timing of verbal parallels can be significant. Some of Oliver's Nasheisms occur for the first time in Saffron-Walden, published in 1596, two years after Dido: the single-use "Gaetulian" as a generalised insult (3.114.4), echoing (Brooke suggests) Dido's contemptuous use of the term for Iarbas; and "shelves" meaning sandbanks (3.130.12-14), although this is a figurative use similar to that

\footnotetext{
${ }^{49}$ McKerrow, Works, 4:296.

${ }^{50}$ In Nashe, "attract" occurs less often than "exhaled": six times, plus "attractive" twice.
} 
of Queen Margaret in 3H6, 5.4.22-36. ${ }^{51}$ "Shelves" as sandbanks used literally occurs for the first time in Lenten (3.161.16), employed (like Dido's instances) as part of a narrative description. The contexts of these late Nasheisms (satire and parody) cast further doubt on the notion of "Nasheisms" as an indicator of authorship. Instances such as "Megaera's eyes" are not belated and retrospective signs of Nashe's presence in Dido - the traces of a collaboration occurring perhaps up to fifteen years earlier-but are embedded in a new context, an affectionate parody of Marlowe's works. Nashe may be displaying his abundant wit, but he is also ensuring that his readers remember and celebrate Marlowe. What the Nasheisms reveal, in these instances at least, is not co-authorship but appropriation. As such, they support a conclusion that the term "Nasheism" is misleading and should be discarded. Considered as evidence, the "Nasheisms" are unreliable, sometimes inconsistent, and often irrelevant; some arise in the narrative, and many are no more than common usage. This analysis of the "available evidence" has shown that it is not sufficient to collect verbal parallelstraditionally, a common approach to questions of authorship - without taking into account their contexts: those distinctive patterns of thought, emotion, and imagination as revealed in "the whole complex pattern of an author's vocabulary."

\section{Approach 2: Computation}

We now turn to quantitative evidence, reviewing earlier studies and presenting some new stylometric work of our own. We begin with patterns in the prosody of Dido, which two scholars have examined with the aim of detecting the sort of variation which would likely result from shared authorship. In his 1960 book Ants Oras compared the pause frequency profiles of Dido with those of the two Tamburlaine plays, i.e., the percentage of pauses occurring on each of the nine internal syllables of a ten-syllable line, judging from their punctuation, and found them to be very similar. ${ }^{52}$ In 2014 Marina Tarlinskaya reported on a search for metrical elements in Dido that would suggest Nashe's hand in the play. She used the verse in Summer's Last Will and Testament as a guide to Nashe's metrical habits. The

\footnotetext{
${ }^{51}$ Margaret describes the York brothers as the "shelves and rocks that threaten us with wreck"; she identifies Clarence as "a quicksand of deceit" and Richard as "a raggèd fatal rock."

52 Ants Oras, Pause Patterns in Elizabethan and Jacobean Drama: An Experiment in Prosody (Gainesville: University of Florida Press, 1960), 65. See the discussion of Oras's results in Freebury-Jones and Dahl, "Searching," 298-99.
} 
verse in the play has a "peculiar," "rough style." 53 She found that "Nothing remotely resembling Nashe's lines occurs in any act of Dido." 54

\section{Merriam and Logometrics}

In 2000 Thomas Merriam offered a "logometric" analysis of Dido which concludes that Marlowe wrote Acts 1-2, possibly with a Nashe insertion within those acts, while Nashe wrote Acts 3-5. Merriam's claims are based upon individual cumulative sum charts for five words, and, but, I, no and not, combined through Principal Component Analysis into a single cumulative sum chart. The chart plots successive moves higher or lower in the component score in the lines of the constituent plays, passing through a composite text made up of 1 Tamburlaine followed by Dido and then Summer.

The reliability of the analysis depends firstly on the fact that each of the five words is an effective marker of Marlowe versus Nashe authorship. This is demonstrably not the case. ${ }^{55}$ While, as Merriam points out, the average count for three Marlowe plays for these words is higher or lower than the count for Summer, the difference is not consistent for all of them, as we can see if we chart the scores for the three plays with that for Nashe's play (Figure 1).

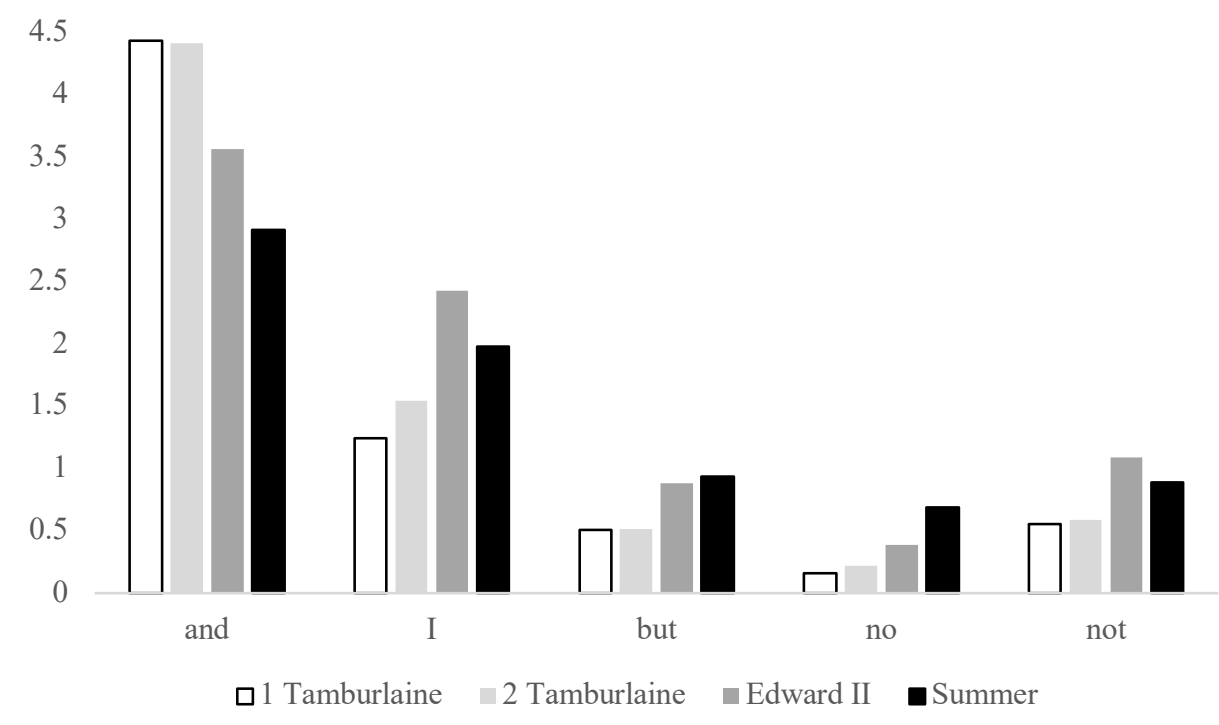

Figure 1: Percentage counts for five words in four plays

\footnotetext{
${ }^{53}$ Marina Tarlinskaja, Shakespeare and the Versification of English Drama, 1561-1642 (London: Ashgate, 2014), 72-3.

54 Tarlinskaja, 74.

${ }^{55}$ An earlier version of the following discussion of Merriam's results, and of the Zeta tests of Nashe's hand in Dido, was presented by one of the current authors (Craig) at the London Forum for Authorship Studies in February, 2012.
} 
The Nashe play is indeed lower on and than the three Marlowe plays, and higher on but and no. In the cases of $I$ and not, there is no clear pattern: a Marlowe play has a higher score than Summer, even though we know the Marlowe average is lower. Edward II comes close to the Summer's score of but (0.88 percent compared to 0.94 percent), making that word-variable a weak marker.

Two of the chosen words are poor markers of a difference between Marlowe and Nashe writing styles, and a third is unconvincing. This disables Merriam's analysis from the beginning, since his next step is to take just one play as representative of Marlowe's style, relying on the five words as sound, generalisable, Marlowe markers.

Merriam places Dido between 1 Tamburlaine and Summer in a continuous composite text, and measures how his component varies in direction. Evidently there is a persistent contrast between scores for lines in 1 Tamburlaine and scores for lines of Summer. However, this is a difference between two plays, not necessarily a difference between authors. These are plays of very different types - a martial romance and a pastoral pageant — and while authorship may have some role in the contrast in their styles, there is no way of detecting how large this role is with this test based on these texts. ${ }^{56}$ Merriam's chart shows that there is a change of direction within Dido, at the end of Act 2, and he takes this as evidence that Marlowe wrote Acts 1 and 2 and Nashe wrote Acts 3 to 5. He has to postulate a Nashe section within Acts 1-2 of Dido to explain an awkward change of direction in the line in this part of the play, which further weakens his case..$^{57}$ There is no telling whether this is a Nashe section, or a third author intervening, or a change of style by a single author for some reason. Merriam's study is flawed in its choice of markers. His assumption that a difference between two plays can serve as a basis for authorial discrimination would be a fundamental weakness, even if his chosen markers were powerful and consistent. In our view his article does not offer any persuasive evidence for Nashe's involvement in the writing of Dido, or against it.

\section{Freebury-Jones and Dahl: Two Quantitative Tests}

The article by Freebury-Jones and Dahl already cited offers two new quantitative tests, neither of which produce any evidence of Nashe's involvement in the play. The first uses the Zeta vocabulary test, which focuses on mid-frequency words, aiming for access to a writer's

\footnotetext{
${ }^{56}$ Merriam mentions that a similar pattern appears if 2 Tamburlaine is substituted for 1 Tamburlaine, but these are very similar works, so this does not offer any substantial confirmation that a wider Marlowe style is being captured in the analysis. See "Marlowe and Nashe," 427n2.

${ }^{57}$ Merriam, 427.
} 
characteristic vocabulary, rather than their characteristic syntax, rhetorical stance or discursive mode. We present results from new tests using the same method later in this essay. The Zeta method was invented by John Burrows; the variant of the test used in FreeburyJones and Dahl's study and by ourselves was first described in a 2009 chapter by Craig and Kinney. It works by identifying two sets of texts, typically those by one author and those by another, and then giving every word that occurs in the texts a score for its relative abundance in one set and rarity in the other. ${ }^{58}$ The theoretical highest score would be given to words that occur in every text sample in one set but never in the other set. Very common words which occur in every sample of every text score zero. (This means that most function words are eliminated.)

One can, for instance, take the 1,000 highest-scoring words and the 1,000 lowestscoring words on the Zeta formula and use these as marker sets. The researcher then counts how many of these words occur in each of the samples in the analysis and converts this into a proportion of all the different words in that sample. A high proportion means that the sample shares a good deal of the characteristic vocabulary of one of the pre-defined sets. If the first set is a group of Marlowe plays and the second set is a group of plays by others, and the sample has a high proportion of the Marlowe words, we can say the sample in question has a "Marlovian" vocabulary.

Each sample has two scores, as already mentioned, and we can plot the samples along two axes, proportions of Set A words, and proportion of Set B words, to visualise the results. If a sample has a high proportion of Set A words and a low proportion of Set B words, the system is attributing it to Set A.

The aim of the method is to classify samples of unknown authorship to one set or the other. To assess the reliability of the method, we need some test samples of known authorship which (like the mystery samples) have not played a part in forming the classifying system, i.e., have not played a part in the formation of the two lists of words.

Freebury-Jones and Dahl carried out their Zeta test with three Nashe prose works and Summer as their Nashe training samples and four Marlowe plays as their Marlowe training set. They include Dido, six Nashe prose works, two Marlowe plays and Marlowe's Hero and

\footnotetext{
${ }^{58}$ John Burrows, "All the way through; Testing for Authorship in Different Frequency Strata," Literary and Linguistic Computing 22 (2007): 27-47; Hugh Craig and Arthur F. Kinney, "Methods," in Shakespeare, Computers, and the Mystery of Authorship, edited by Hugh Craig and Arthur F. Kinney (Cambridge: Cambridge University Press, 2009), 15-39. Christof Schöch et al. have recently proposed a variation on the formula for Craig's Zeta, using logarithmic transformations of the proportions of presences and absences in the text sets. See "Burrows' Zeta: Exploring and Evaluating Variants and Parameters," ADHO Digital Humanities Conference (2018), https://dh2018.adho.org/burrows-zeta-exploring-and-evaluating-variants-and-parameters/.
} 
Leander as test samples, none of them having contributed to the selection of marker words.

They say they considered only the 14,000 most common words in their training sets, and used David Hoover's Excel spreadsheets for Zeta, so presumably they selected the words which appear regularly in Marlowe and rarely in Nashe, to form a Marlowe-not-Nashe list, and then the words which appear regularly in Nashe and rarely in Marlowe to form a Nashe-notMarlowe list. ${ }^{59}$ The proportions of Marlowe-not-Nashe words appearing in a segment were then plotted on the $\mathrm{X}$ axis and the proportions of Nashe-not-Marlowe words are plotted on the $\mathrm{Y}$ axis.

Their Figure 2 shows that the Nashe test segments score generally higher on Nashenot-Marlowe words and lower on Marlowe-not-Nashe words than Marlowe test segments. The classifier they have set up is therefore successful in attribution with segments of known provenance. The Dido segments all fall within the cluster of Marlowe test segments, i.e., they are all attributed to Marlowe. Nothing in the test suggests that Nashe had any hand in the play.

The authors note that words in the various text sets they used remain in their original, highly variable, spelling, i.e., are not modernised, and that stage directions are included in the counts for the plays in the various sets. ${ }^{60}$ Despite these two potentially confounding factors, which would normally be removed for tests like these, the results show a good separation of the control sets of Marlowe and Nashe, and of the test sets from the two authors, and place the Dido segments clearly with the Marlowe test set segments.

In a second quantitative test, the authors counted rare phrases: three or more contiguous words, occurring in Dido and in the base canon of an author but not elsewhere in a large comparison set. In the event the occurrence of Marlowe rare phrases in Dido as a percentage of the total running words of the Marlowe texts included is 0.03 , while the occurrence of Nashe phrases, when put on the same percentage basis, is much lower, comparable with that of other authors like Greene, Peele, Lodge, and Shakespeare, who are not suspected of involvement in the writing of Dido.

In this test Dido was not divided into segments but treated as a whole work, so the usefulness of this finding is limited, since it does not address the possibility of local

\footnotetext{
59 They do not say how many marker words were selected for their test. They report that "The 14,000 most frequent words from Marlowe and Nashe Groups 1 were compared to Marlowe and Nashe Groups 2, with Dido used as the holdout test text," but presumably they mean that a selection from the 14,000 words was used to form lists of words favoured by Marlowe and by Nashe, and that Dido along with all their "Group 2" works was held out for testing (300).

${ }^{60}$ Freebury-Jones and Dahl, "Searching," 300-1.
} 
concentrations of Nashe phrases. The argument for Nashe's involvement starts with his name appearing after Marlowe's on the title page of the play, as part author, and since the late seventeenth century proponents of Nashe's hand have generally argued that he contributed parts of the play, rather than the whole, so tests taking the play as a single undivided unit are of limited value as evidence, given the terms of the debate. Nevertheless, we do learn that in Dido as a whole rare Nashe phrases are only as common as rare Greene phrases, or rare Peele phrases, proportionate to the size of the authorial canons used for the test, and not much more common than rare Shakespeare or rare Lodge phrases.

\section{New Zeta Tests}

We now offer our own tests, fresh applications of the Zeta method already discussed. We focus on the imbalance in literary modes inherent in the problem of Nashe's putative collaboration with Marlowe in Dido. There is abundant surviving Nashe prose to provide a Nashe signature but only one play (Summer). This makes for a difficulty, since it is reasonable to expect that the differences between non-dramatic prose and play dialogue would tend to cut across authorial difference, and it is a play which is the target of our investigation.

To assess whether this factor is in play in our trials, we reserve Summer as a test case. If a Nashe-versus-other authorial separation is working despite the difference in modes, then the Nashe play should be classified with Nashe and away from the set of plays by others. In this case spelling is modernised throughout and paratextual material like prefaces, stage directions, and speaker names is omitted.

Since the hypothesis is that Nashe contributed parts of Dido, rather than the whole of the play, we divide all the plays and prose works in the study into segments, each of 2,000 words, slightly larger segments than those chosen by Freebury-Jones and Dahl. The final segment for each work includes any words left over. An average play is 19,000 words, so we can expect nine segments per play. An act will cover one or more often two segments. Experience has shown that 2,000 words is a reasonable balance between a fine-grained sampling, which is important when we don't know the boundaries between authorial contributions, and a sufficient size to bring the law of large numbers into play, i.e., the law that a large sample will be closer to the true underlying average than a small sample, which may be dominated by a local idiosyncrasy. This is the standard segment size adopted for the studies in the 2009 collection of Shakespeare attribution essays edited by Craig and Kinney. 
Our version of Dido as modernised has 13,529 words, excluding stage directions and speaker tags, and yields six segments, five of 2,000 words and the last comprising 3,529 words.

\section{Our Corpus of Plays and Prose Works}

The corpus available to us consists of 275 plays with first performances $1538-1642 .{ }^{61}$

Generally, earlier printed editions are preferred to later ones as copytexts for the machinereadable versions, and only one version per work is included. As already noted, stage directions, speaker tags, and prefatory matter are marked off and excluded from the word counts. Spelling was modernised manually with the aid of the VARD 2 variant detector software package. ${ }^{62}$

For a Marlowe signature we use Doctor Faustus (A text, 1604), Edward II, Jew of Malta, Massacre at Paris, and the two parts of Tamburlaine. Here we confront the uncomfortably uncertain nature of the attribution and transmission of early modern drama. There are well established problems with the provenance of these plays-Doctor Faustus is likely to be collaborative, The Jew of Malta may well be revised by another writer, and the surviving The Massacre at Paris seems to be a corrupt version. ${ }^{63}$ Nevertheless, we persisted with the full set in order to keep as full a picture as possible.

We have six Nashe prose works available, Preface to Menaphon (1589), Pierce Penniless (1592), Strange News (1592), Unfortunate Traveller (1594), Have With You To Saffron Walden (1596), and Nashes Lenten Stuffe (1599). These are based on the early printed versions. As with the play corpus, extraneous matter like headings has been marked off and excluded, and spelling modernised.

227 plays from the corpus are well-attributed to authors other than Marlowe or Nashe, and we use these in our second study. In both studies we use lists of 1,000 words which are characteristic of each of the two opposed "training" groups in the analyses.

\footnotetext{
${ }^{61}$ These play texts are available from the authors on request, along with the prose texts mentioned below. 62 Alistair Baron and Paul Rayson, "VARD 2: A tool for dealing with spelling variation in historical corpora," Proceedings of the Postgraduate Conference in Corpus Linguistics (Aston University, Birmingham, UK, 22 May 2008).

${ }^{63}$ On Faustus see Eric Rasmussen, A Textual Companion to "Doctor Faustus” (Manchester: Manchester University Press, 1993), 62-75; on The Jew of Malta see David J. Lake, "Three Seventeenth-Century Revisions: Thomas of Woodstock, The Jew of Malta, and Faustus B," Notes \& Queries 228 (1983), 138-42; on The Massacre at Paris see Laurie E. Maguire, "Marlovian Texts and Authorship," The Cambridge Companion to Christopher Marlowe, ed. by Patrick Cheney (Cambridge: Cambridge University Press, 2004), 45-46 and Thomas Pettitt, "Towards the Zielform: The Oral Decomposition of Marlowe's 'Bad' Texts," Comparative Drama 39 (2006 for 2005), 224-26.
} 


\section{Nashe versus Marlowe and Dido}

In the first trial we use the six Nashe prose works and the six Marlowe plays as the so-called "training sets" which determine the lists of marker words. This is thus a direct NasheMarlowe comparison, albeit across the divide between drama and non-dramatic prose. As "test" specimens we included the segments of Dido and of Summer. This is an opportunity to revisit the comparison in Freebury-Jones and Dahl, with a different selection of texts, and a different approach to preparing the texts for analysis.

Figure 2 shows how the scores on the two axes, proportions of Nashe words and proportions of Marlowe words, placed the various segments.

- Nashe prose Marlowe plays (no Dido) OSummer $\Delta$ Dido

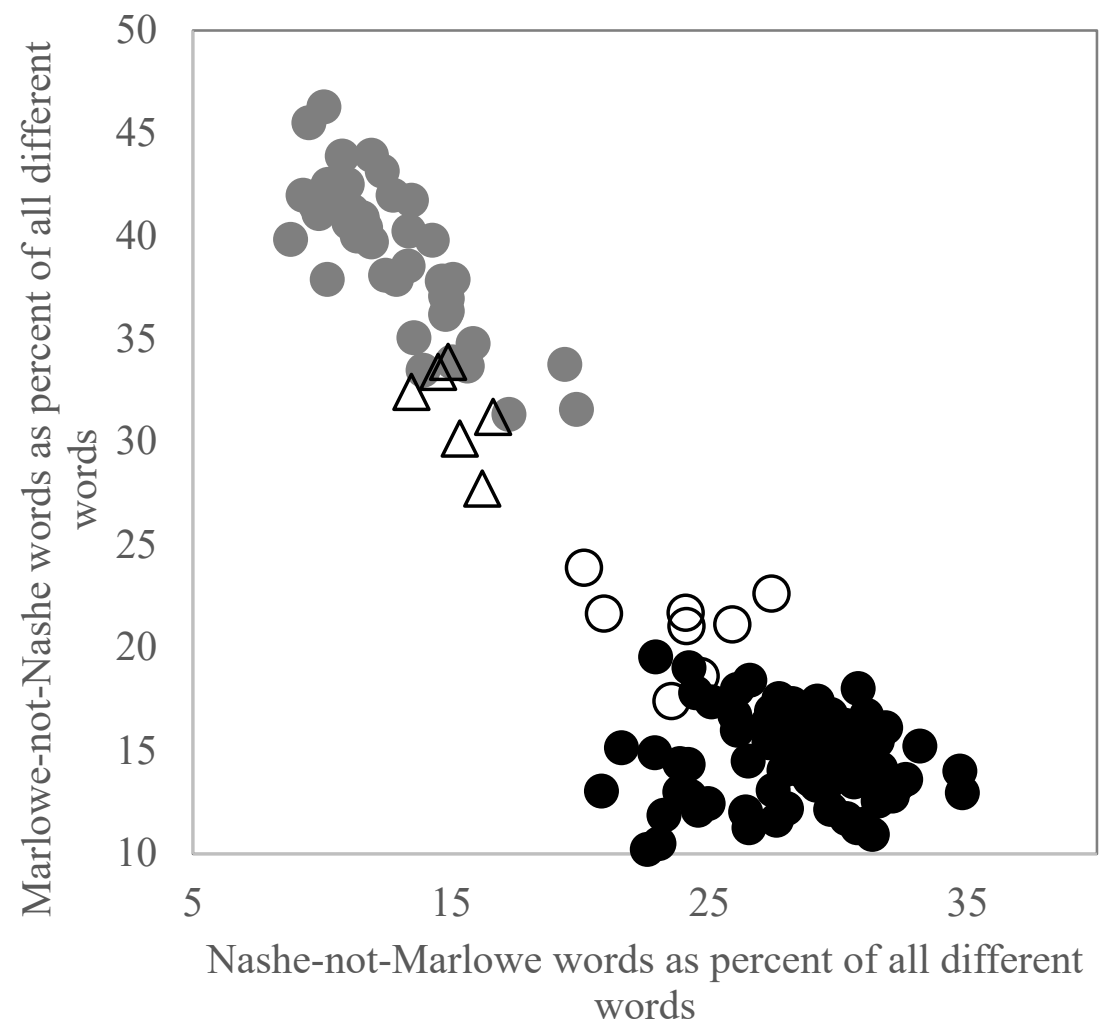

Figure 2: Zeta vocabulary test: Nashe prose vs. Marlowe plays, with Summer and Dido as test cases

The two training sets are completely separated in both dimensions, just separated on the $X$ axis - the lowest Nashe segment has a fractionally higher score than the highest Marlowe segments in terms of proportions of Nashe words - and widely separated on the Y axis, proportions of Marlowe words. Summer segments are grouped with the Nashe segments, 
showing that in this case the authorial difference prevails over the difference in mode. The Dido segments cluster with the Marlowe segments. Admittedly three segments score generally lower than the regular Marlowe segments, but this would not be unexpected even for an authentic Marlowe segment, since Dido, unlike the Marlowe training segments, was not used to select the marker words. We could expect any Marlowe segments reserved as a test set to have lower Marlowe and higher Nashe scores, because of the rule of regression to the mean: a random freshly introduced Marlowe segment will likely have a lower proportion of the words elsewhere defined as Marlowe than works used to establish the word list, the list being "tuned" to that particular group of works.

This trial gives some confidence that the method can recognise a segment of Nashe drama as Nashe, and gives no grounds to attribute any part of Dido to Nashe.

\section{Nashe versus a Mixed-Author Set of Plays, with Dido}

The Nashe versus Marlowe trial is well targeted to the particular problem, but we may also be interested in a more broad-based comparison, between the Nashe prose works and the drama of the time in general. For this we can establish a set of plays which are well attributed to authors - we omit plays of uncertain authorship — and exclude the Nashe play and the Marlowe plays from this set. As already noted, there are 227 plays which fit this description within the overall drama set of 275 .

We can then establish marker word sets for Nashe prose versus the drama of the period in general. These are words that Nashe uses often but the plays of the time do not, and correspondingly words that occur frequently in the plays of the time and rarely in the chosen Nashe works. Using these lists, we can then plot segments of Summer, Dido and the other six Marlowe plays. This time the definition of the marker word lists is independent of the Marlowe works, so questions of authenticity in the training sets do not arise and we can largely escape the conundrum already alluded to of the "indeterminacy" of Marlowe's texts.

This time the separation of the training set is not complete on either axis but the clusters (black and pale grey) are separate if we take both axes into account. The method does not work so well in placing Summer with Nashe, as we know it should from an authorial point of view. This might be expected, since we have moved from a narrow-spectrum comparison of two authors to a differentiation which puts Nashe against a very varied set of plays by multiple authors. Nevertheless, the Summer segments are generally placed to the lower and right-hand end of the "other drama" cluster, indicating some affinity with Nashe prose. 
Who Wrote Dido, Queen of Carthage?

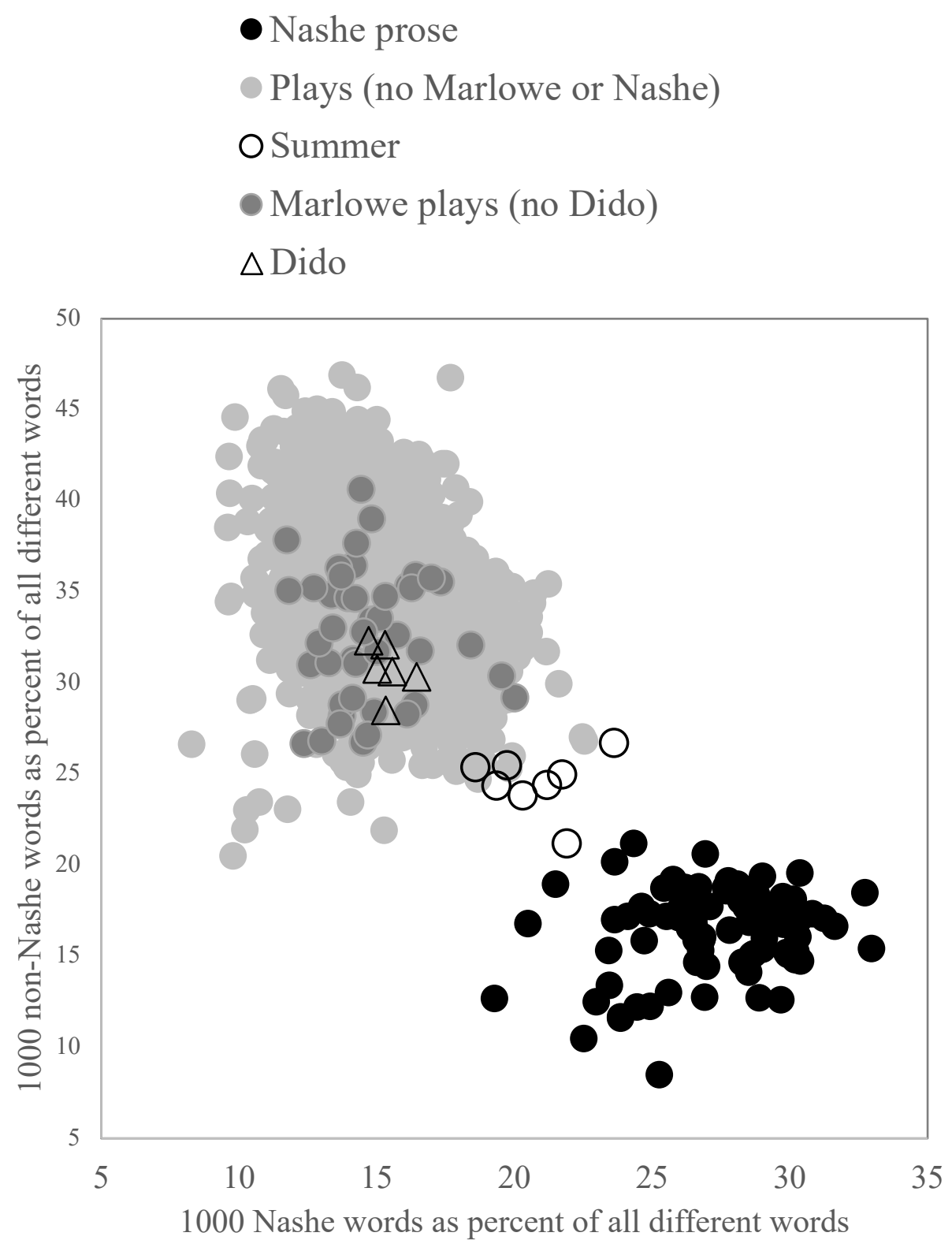

Figure 3: Zeta vocabulary test: Nashe prose vs. plays by others, with Marlowe plays and Summer as test cases

The Marlowe segments are all placed inside the "other drama" cluster. The Dido segments (marked with hollow triangles) appear as regular Marlowe segments, with no sign of any unusual affinity in the word-list scores with Nashe prose.

There are again no grounds here to detect any Nashe hand in any part of Dido. The method shows some power in attributing Marlowe play test segments to "other drama" rather than Nashe prose and Summer to Nashe, and it places all the Dido segments with Marlowe drama. 


\section{Computation: Conclusions}

Patterns of word use analysed computationally with more reliable methods than Merriam's, as well as Oras's and Tarlinskaya's analysis of prosody, suggest that Marlowe was the sole author of the play. No reliance can be placed on Merriam's logometric study attributing Acts 3-5 of Dido to Nashe. The Zeta tests pitting Marlowe against Nashe in Freebury-Jones and Dahl and in the current article both place all the Dido segments with Marlowe, and away from Nashe. In another Zeta test, contrasting a larger body of plays of mixed authorship with Nashe prose works, the segments of Dido are placed with the plays by other authors and away from the Nashe cluster. There are inevitable shortcomings in all these analyses, deriving principally from the fact that Nashe did not leave a body of plays which can provide a satisfactory standard of comparison for possible involvement in writing dramatic dialogue in the manner of Dido. None of the methods could claim to rule out the presence of very minor contributions by a second author like Nashe. Nevertheless, this computational work allowed a Nashe style every chance of appearing in Dido if it were present, and it did not, while Nashe's one surviving play did cluster with his prose work. This leaves intact the finding of the first part of this essay, i.e., that there is no evidence worth the name that Nashe wrote any part of Dido, beyond the appearance of his name on the title page.

\section{General Conclusion: A Question of Presence}

Thomas Nashe was not the co-author of Dido, Queen of Carthage: that is the conclusion which our re-considered and new evidence — traditional, "available," and computational— leads to. This finding does not explain Nashe's name on Dido's title page, a problem which deserves a more adequate answer than Tanner's "edidit et perfecit" nearly three hundred years ago, or its multiple paraphrases since. Although collaboration in playwriting was common and both Marlowe and Nashe have been proposed as sharers in other plays, there is a limit to the kinds of collaboration that could be accommodated by the title page's "written by." "Transcribing" a manuscript should not qualify, and "publishing" a play required money. As for Gill's "literary executor," Wiggins remarks that "scrupulous and dutiful literary executors are not normally named as co-authors on the title ages of their dead friends' work." ${ }^{\prime 4}$ Even if - and the evidence suggests the possibility is remote-Nashe added a word here and there, that is not a basis for a claim to co-authorship. The solution may be something

\footnotetext{
${ }^{64}$ Wiggins, "When," 525.
} 
quite simple: mistakes were sometimes made on title pages, and Dido's may well record one such error. ${ }^{65}$

The need for a new narrative about the title page is one implication of our study; another is the opportunity to redefine Nashe's relationship with Marlowe. Some items in the "available evidence" offer no particular connection, but others suggest, not that Nashe has a "presence" in Dido, but effectively the reverse: that Dido has a presence in Nashe. This is a presence which needs to be characterised in a different way, one which is not identified with authorship but which recognises Nashe's echoing and appropriating of Dido, following his practice with numerous other texts, ancient and contemporary. The Nasheisms listed by Oliver in Lenten are few, but they indicate that Nashe responded to Dido, as he did to Hero and Leander, with a characteristic pattern of expression: satirical, affectionate, and witty, engaged in transforming lyricism and even hyperbole into the inflated and absurd. But that pattern of response may have operated earlier, quite possibly in 1593, when Nashe was writing Traveller. ${ }^{66}$ He recorded finishing this in late June 1593, four weeks after Marlowe's death in May, but it was not published until 1594, and probably after Dido. ${ }^{67}$ If the manuscript of Dido were circulating in the early 1590s, it is not impossible that Nashe had access, perhaps while he was writing or revising Traveller. ${ }^{68}$ Three of Oliver's Nasheisms ("Dolon," "ticing," ["tice”], "[take] soil”) occur first in Traveller; "ticing” is found again,

\footnotetext{
${ }^{65}$ On title page inaccuracies, see Lukas Erne, Shakespeare as Literary Dramatist (Cambridge: Cambridge University Press, 2003), 36, and Vickers, Shakespeare Co-Author, 10. At least one detail on the Dido title page is wrong: Nashe was not a "Gent," having left Cambridge without completing his MA. He is described as a "Gentleman" on the title pages of Pierce and Strange News. The latter includes a statement rejecting this "vain title" and blaming the printer for the error (1.311.30-312.3); nevertheless, both works continued to be published as by Thomas Nashe "Gent." or "Gentleman" as late as 1595. Oliver comments that Nashe was not "the kind of man to keep quiet about such an attribution if he were not entitled to it" (Dido, xxiii). On the other hand, while there is evidence that Nashe saw at least some of his works through the press, there is no such evidence for Dido. See note 36 on the compositorial characteristics of the text. In any case, Nashe would have had few opportunities to be involved in the printing or to remove his name and the "Gent" from the title page. After Marlowe's death at the end of May, he completed two lengthy works during September, was imprisoned in November, and spent the festive season with the Careys in the Isle of Wight, probably returning to London in February 1594, with Traveller to see through the press. He arrived back late in the process: for his list of corrections published with the first edition, see McKerrow, Works, 2:203. He explains the reasons: "in my absence (through the printer's oversight, and my bad writing)."

${ }^{66}$ Feasey and Feasey suggest Marlowe himself is present in Traveller, in the figure of the poet, the Earl of Surrey, and in Nashe's description of the satirist Aretine. See Lynette Feasey and Eveline Feasey, "Nashe's Unfortunate Traveller: Some Marlovian Echoes," English: The Journal of the English Association 7, no. 39 (Autumn 1948): 125-29. They note a few possible verbal echoes of Dido, including the reference to stars falling (Traveller 2.254.16; cf. Dido 4.4.53-4).

${ }^{67}$ Traveller: date recorded at end of first edition: 27 June 1593; SR entry, 17 September 1593; two editions in 1594.

${ }^{68}$ On Dido's influence on Shakespeare in the late 1580s and early 1590s, see Laurie Maguire and Emma Smith, "What is a Source? Or How Shakespeare Read his Marlowe." Shakespeare Survey 68 (2015): 15-31.
} 
with "[take] soil," in Tears, which was written immediately after Traveller and published in $1593 .{ }^{69}$

Perhaps the most intriguing sign of Dido's presence in Nashe in 1593-1594, however, is a sonnet supposedly written by the Earl to the aforementioned little bird-woman, Diamante. This is a parody of Petrarchan excess, achieved by creating absurd extensions of Marlovian hyperbole. The opening echoes Faustus and Helen, and possibly Dido, with the Carthage queen also anticipating immortality with a kiss: "But in his looks I see eternity, / And he'1l make me immortal with a kiss" (4.4.122-3).

If I must die, oh, let me choose my death.

Suck out my soul with kisses, O cruel maid, In thy breasts' crystal balls embalm my breath, Dole it all out in sighs when I am laid.

Thy lips on mine like cupping glasses clasp, Let our tongues meet and strive as they would sting.

Crush out my wind with one straight girting grasp,

Stabs on my heart keep time whilst thou dost sing.

Thy eyes like searing irons burn out mine,

In thy fair tresses stifle me outright,

Like Circes change me to a loathsome swine,

So I may live forever in thy sight.

Into heaven's joys none can profoundly see,

Except that first they meditate on thee. (Traveller, 2.262.34-263.12)

Here we have, amongst the images of succubas and embalming and bloodletting and suffocation, not just those burning eyes from the Elegies and Tamburlaine and Dido-and possibly Dido's arms that "coll me round about" (4.3.51), "Heaven, envious of our joys" (4.4.52), and "in his looks I see eternity" (4.4.122)—but the very lips and tongues that chain Aeneas to Dido:

“Come back, come back!" I hear her cry afar,

"And let me link thy body to my lips,

That tied together by the striving tongues

We may as one sail into Italy." (4.3.27-30)

"Strife" and "striving" occur numerous times in both Marlowe and Nashe, but not elsewhere in conjunction with "tongues." There are four mentions of tongue-kissing in Marlowe's translation of Ovid's Amores, but none is described in such vigorous terms: "purloin," "lay, "hid," “dips" (2.5.24, 57-8), "eagerly" (3.6.9), and (least active) "There in your rosy lips my tongue entomb" (3.13.23). In Nashe's Choice of Valentines, the woman just lies back and

\footnotetext{
${ }^{69}$ Tears: SR entry, 8 September 1593; published within days.
} 
"waggles with her tongue" (97); "striving" does happen somewhat later ("Thus gazing and thus striving we persevere," 177), but the activities described there do not include tongues. Indeed, Nashe's particular pattern of response may have operated earlier still. Summer's Last Will and Testament, Nashe's play for boys, ends with a memorable dramatic moment: a “pretty boy” sits on Will Summer's knee to read the Epilogue with its magnification of Vulcan dancing. This could well be another witty but affectionate parody, this time of Dido's opening scene, with visual and verbal echoes activated perhaps by a memory of the play's performance. $^{70}$

\section{Rewriting Narratives}

Nashe has a connection with Dido, but it is not one of co-authorship, and the term "Nasheism" is not worth retaining. In rewriting that narrative, there is scope for an exploration of Nashe's links with Dido, with Traveller offering a potential starting point. ${ }^{71}$ As for Dido, Queen of Carthage, this has been an essay about evidence. We have used two very different approaches, yet we both conclude that the play is unlikely to have been in any sense a co-authored text. In simple terms, the title page is wrong. Christopher Marlowe wrote Dido, Queen of Carthage.

\section{Bibliography}

Abbott, E. A. A Shakespearian Grammar. Rev. ed. New York: Haskell House, 1972.

Bakeless, John. The Tragicall History of Christopher Marlowe. 2 vols. Westport, CT: Greenwood Press, 1942.

Baron, Alistair, and Paul Rayson. 2008. "VARD 2: A tool for dealing with spelling variation in historical corpora." Proceedings of the Postgraduate Conference in Corpus Linguistics, Aston University, Birmingham, UK, 22 May 2008.

Boas, Frederick S. Christopher Marlowe. Oxford: Clarendon Press, 1940.

\footnotetext{
${ }^{70}$ Summer was most likely performed in 1592 but not published until 1600 (SR entry, 28 October 1600). Per Sivefors, in "Underplayed Rivalry: Patronage and the Marlovian Subtext of Summer's Last Will and Testament," Nordic Journal of English Studies 4, no. 2 (2005): 65-87, notes verbal echoes of Tamburlaine and Edward, with a possible echo of the morning's "grey uprise" in Dido (1.1.102).

${ }^{71}$ However they are defined, the connections between Dido and Nashe appear to increase from 1593, with almost half of the Nasheisms recorded from that year. First occurrences in 1593 or later: soil, tice, bed-red, Dolon. Gaetulian, shelves, Megaera's eyes, glassy fields. "Bed-red" first appears in Terrors of the Night, written early 1593 but not published until 1594 (the SR entries are 30 June 1593 and 25 October 1594); the parallel with Dido is unremarkable, with both instances used literally of the sick or elderly. Later, in Saffron-Walden, Nashe refers to Harvey's writings as "bedred stuff" that must "limp out of Paul's Churchyard" (3.35.20).
} 
Bowers, Fredson. The Complete Works of Christopher Marlowe: Volume 1. Cambridge: Cambridge University Press, 1973.

Brooke, C. F. Tucker. “The Marlowe Canon.” PMLA 37, no. 3 (September 1922): 372-4. “Marlowe's Versification and Style.” Studies in Philology 19, no. 2 (April 1922): $186-205$.

, ed. The Life of Marlowe and The Tragedy of Dido Queen of Carthage. 1930; Reprint, New York: Gordian, 1966.

, ed. The Works of Christopher Marlowe. Oxford: Clarendon, 1910.

Bullen, A. H., ed. The Works of Christopher Marlowe. 3 vols. London: Nimmo, 1885.

Burnett, Mark Thornton, ed. Christopher Marlowe: The Complete Plays. London: Dent, 1999. Everyman.

Burrows, John. "All the Way Through: Testing for Authorship in Different Frequency Strata." Literary and Linguistic Computing 22 (2007): 27-47.

Craig, Hugh, and Arthur F. Kinney. "Methods." In Shakespeare, Computers, and the Mystery of Authorship, edited by Hugh Craig and Arthur F. Kinney, 15-39. Cambridge: Cambridge University Press, 2009.

Crystal, David and Ben Crystal. Shakespeare's Words: A Glossary and Language Companion. London: Penguin, 2002.

Dessen, Alan C. and Leslie Thomson. A Dictionary of Stage Directions in English Drama, 1580-1642. Cambridge: Cambridge University Press, 1999.

Dyce, Alexander, ed. The Works of Christopher Marlowe: With Some Account of the Author, and Notes: A New Edition, Revised and Corrected. London: Routledge, 1876.

Erne, Lukas. Shakespeare as Literary Dramatist. Cambridge: Cambridge University Press, 2003.

Feasey, Lynette, and Eveline Feasey. "Nashe's Unfortunate Traveller: Some Marlovian Echoes." English: The Journal of the English Association 7, no. 39 (Autumn 1948): 125-29.

Fehrenbach, Robert J., Lea Ann Boone, and Mario A. Di Cesare. A Concordance to the Plays, Poems, and Translations of Christopher Marlowe. Ithaca, NY: Cornell University Press, 1982.

Freebury-Jones, Darren, and Marcus Dahl. "Searching for Thomas Nashe in Dido, Queen of Carthage." Digital Scholarship in the Humanities 35, no. 2 (2020): 296-306. 
Gill, Roma, ed. The Complete Works of Christopher Marlowe, Vol. 1: Translations. Oxford: Clarendon, 1987.

Grosart, Alexander, ed. The Complete Works of T. Nashe. 6 vols. The Huth Library, 1885. Hendricks, Margo. "Managing the Barbarian: The Tragedy of Dido, Queen of Carthage." Renaissance Drama 23 (1992): 165-88.

Heninger, S. K. A Handbook of Renaissance Meteorology: With Particular Reference to Elizabethan and Jacobean Literature. Durham, NC: Duke University Press, 1960. Hunter, G. K. English Drama 1586-1642. Oxford: Clarendon Press, 1997.

Hurst. Dido, Queen of Carthage: A Tragedy, by Christopher Marlowe and Thomas Nash. The Old English Drama: A Selection of Plays from the Old English Dramatists, Volume 2. London: Hurst, Robinson \& Co., 1825.

Kuriyama, Constance Brown. Christopher Marlowe: A Renaissance Life. Ithaca, NY: Cornell University Press, 2002.

Lake, David J. “Three Seventeenth-Century Revisions: Thomas of Woodstock, The Jew of Malta, and Faustus B.” Notes \& Queries 228 (1983): 138-42.

Maclure, Millar. Marlowe: The Critical Heritage 1588-1896. London: Routledge \& Kegan Paul, 1979.

Maguire, Laurie E. "Marlovian Texts and Authorship.” In Cambridge Companion to Christopher Marlowe, edited by. Patrick Cheney, 41-54. Cambridge: Cambridge University Press, 2004.

Maguire, Laurie and Emma Smith. "What is a Source? Or How Shakespeare Read his Marlowe." Shakespeare Survey 68 (2015): 15-31.

McKerrow, Ronald B., ed. The Works of Thomas Nashe. 5 vols. 1904-10. Revised by F. P. Wilson. Oxford: Basil Blackwell, 1966.

Melnikoff, Kurt. Elizabethan Publishing and the Makings of Literary Culture. Toronto: University of Toronto Press, 2018.

Merriam, Thomas. "Marlowe and Nashe in Dido Queen of Carthage." Notes \& Queries 245 (December 2000): 425-8.

OED. Oxford English Dictionary Online.

Oliver, H. J., ed. Dido, Queen of Carthage and The Massacre at Paris. Manchester: Manchester University Press, 1968.

Oras, Ants. Pause Patterns in Elizabethan and Jacobean Drama: An Experiment in Prosody. Gainesville: University of Florida Press, 1960. 
Oxberry, W., ed. Dido, Queen of Carthage: A Tragedy, by Christopher Marlowe. London, 1818-1820 or 1827.

Pearce, T. M. “Evidence for Dating Marlowe's Tragedy of Dido.” In Studies in the English Renaissance Drama, edited by Josephine W. Bennett, Oscar Cargill and Vernon Hall, Jr., 231-47. New York: New York University Press, 1959.

Pettitt, Thomas. "Towards the Zielform: The Oral Decomposition of Marlowe's 'Bad' Texts." Comparative Drama 39 (2006 for 2005): 213-42.

Rabelais, François. Le quart livre des faits et dits herö̈ques du bon Pantagruel. 1552. Egham, Surrey: Runnymede Books, 1990.

Rasmussen, Eric. A Textual Companion to “Doctor Faustus.” Manchester: Manchester University Press, 1993.

Romany, Frank, and Robert Lindsey, eds. Christopher Marlowe: The Complete Plays. London: Penguin, 2003.

Schöch, Christof, et al. "Burrows' Zeta: Exploring and Evaluating Variants and Parameters." ADHO Digital Humanities Conference. 2018. https://dh2018.adho.org/burrows-zetaexploring-and-evaluating-variants-and-parameters/

Sivefors, Per. 'Underplayed Rivalry: Patronage and the Marlovian Subtext of Summer's Last Will and Testament." Nordic Journal of English Studies 4, no. 2 (2005): 65-87.

Smith, Mary Elizabeth. "Love Kindling Fire”: A Study of Christopher Marlowe's The Tragedy of Dido Queen of Carthage. Salzburg: Institut für Englische Sprache und Literatur, Universität Salzburg, 1977.

Stump, Donald. “Marlowe's Travesty of Virgil.” Comparative Drama 34, no. 1 (Spring 2000): 79-107.

Tarlinskaja, Marina. Shakespeare and the Versification of English Drama, 1561-1642. London: Ashgate, 2014.

Taylor, Gary, John Jowett, Terri Bourus and Gabriel Egan, eds. The New Oxford Shakespeare: The Complete Works. Oxford: Oxford University Press, 2017.

Taylor, Gary, and Rory Loughnane. "The Canon and Chronology of Shakespeare's Works." In The New Oxford Shakespeare Authorship Companion, edited by Gary Taylor and Gabriel Egan, 417-602. Oxford: Oxford University Press, 2017.

Ule, Louis. A Concordance to the Works of Thomas Nashe. 2 vols. Zurich: OlmsWeidemann, 1997.

Vickers, Brian. Shakespeare Co-Author: A Historical Study of Five Collaborative Plays. Oxford: Oxford University Press, 2002. 
Who Wrote Dido, Queen of Carthage?

Wiggins, Martin. “When Did Marlowe Write Dido, Queen of Carthage?” Review of English Studies 59, no. 241 (2008): 521-41.

Wiggins, Martin, and Catherine Richardson. British Drama, 1533-1642: A Catalogue. 9 vols. Oxford: Oxford University Press, 2012-2018.

Williams, Deanne. “Dido, Queen of England.” English Literary History 73, no. 1 (2006): 3159. 